\title{
The bronze liver of Piacenza
}

\section{Thomas M. van Gulik}

Department of Surgery, Amsterdam University Medical Centers, University of Amsterdam, Amsterdam, The Netherlands

Correspondence to: Thomas M. van Gulik. Department of Surgery, Amsterdam University Medical Centers, University of Amsterdam, Amsterdam, The Netherlands. Email: t.m.vangulik@amsterdamumc.nl.

Submitted Jul 19, 2021. Accepted for publication Jul 31, 2021.

doi: $10.21037 / \mathrm{hbsn}-2021-17$

View this article at: https://dx.doi.org/10.21037/hbsn-2021-17

An Etruscan model of a sheep's liver cast in bronze (the cover image) was found in a field near Piacenza, a small town not far from Milan in Italy. Etruscan oracles could predict the future based on the shape and position of the liver lobes of sheep, an art called 'hepatoscopy' (1).

The model is around 7.5 to $12.5 \mathrm{~cm}$ and is roughly dated to the year $100 \mathrm{BCE}$. It shows the visceral side of a sheep's liver, divided by lines into quadrants, which were, in turn, divided into four additional regions. The regions corresponded with the territories of the gods in the universe as indicated by their names engraved in the regions.

In the Etruscan model, the liver is reversed, with the convex part of the gallbladder pointing down. On the right side of the gallbladder, we find a pyramid-shaped structure that was referred to as the processus pyramidalis corresponding with the caudate lobe in humans. On the other side of the gallbladder, we see a protrusion that was called the processus papillaris corresponding with the paracaval part of the caudate lobe. Variations in appearance of these two structures formed the basis for reading the organ in divination. When important decisions had to be made, a sheep's liver would be consulted and the final decision thus placed in the hands of the gods.

\section{Acknowledgments}

The Etruscan bronze sheep's liver is on display in the Musei Civici di Palazzo Farnese, the archaeological museum in Piacenza.

Funding: None.

\section{Footnote}

Provenance and Peer Review: This article was commissioned by the editorial office, Hepatobiliary Surgery and Nutrition. The article did not undergo external peer review.

Conflicts of Interest: The author has completed the ICMJE uniform disclosure form (available at https://hbsn. amegroups.com/article/view/10.21037/hbsn-2021-17/coif).

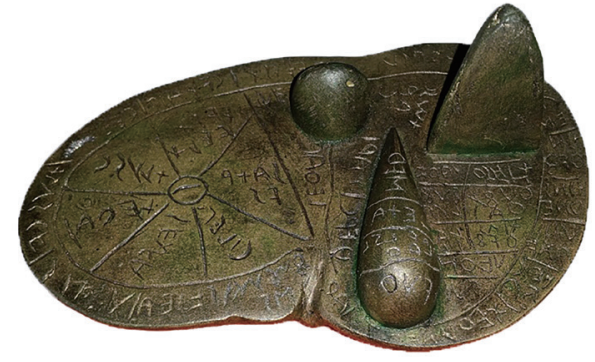

TMvG serves as an unpaid editorial board member of Hepatobiliary Surgery and Nutrition. The author has no other conflicts of interest to declare.

Ethical Statement: The authors is accountable for all aspects of the work in ensuring that questions related to the accuracy or integrity of any part of the work are appropriately investigated and resolved.

Open Access Statement: This is an Open Access article distributed in accordance with the Creative Commons Attribution-NonCommercial-NoDerivs 4.0 International License (CC BY-NC-ND 4.0), which permits the noncommercial replication and distribution of the article with the strict proviso that no changes or edits are made and the original work is properly cited (including links to both the formal publication through the relevant DOI and the license). See: https://creativecommons.org/licenses/by-nc-nd/4.0/.

\section{References}

1. Turfa JMI, Gettys S. The skill of the Etruscan Haruspex. A biological basis for succesful divination? BABESCH 2009;84:41-52.

Cite this article as: van Gulik TM. The bronze liver of Piacenza. HepatoBiliary Surg Nutr 2021;10(4):433. doi: 10.21037/hbsn-2021-17 